\title{
REFLEKSJE \\ O PISARSTWIE STATYSTYCZNYM
}

\section{Walenty Ostasiewicz}

Uniwersytet Ekonomiczny we Wrocławiu

ISSN 1644-6739

DOI: $10.15611 /$ sps.2014.12.19

\section{Grafia o sztucznym demosie, czyli grafomania}

Pierwsze prace nazywane dzisiaj statystycznymi dotyczyły zbiorowości ludzkich nazywanych z łacińska populacjami. Samą naukę o charakterze ilościowym początkowo nazwano demologią, później demografią, od greckiego słowa demos oznaczającego lud. Demografia jest więc nauką dostojną nie tylko ze względu na swe metody i zastosowania, ale jej dostojeństwo potwierdzają i wiek, i to, że dotyczy ona rzeczy najcenniejszej, a mianowicie życia człowieka. To, że populacjami zaczęto z biegiem czasu nazywać zbiorowości innych istot żyjących, można zrozumieć i w pełni zaakceptować. Nazywanie populacjami zbiorowości przedmiotów wytworzonych czy wyprodukowanych przez człowieka i niemających nic wspólnego z życiem, a ich opis nazywać demografią, i do tego traktować to jako naukę, można by uznać za aberrację użycia rozumu ludzkiego. Ale, jak zwykle, sądy pochopne mogą być dalekie od prawdy. Wiadomo, że prawie wszystkie firmy narażone są na ryzyko bankructwa. Od dość dawna wiadomo, że firmy mają osobowość, jest ona nadawana w majestacie prawa, wiadomo jest też od dawna, że większość cech tej osobowości to cechy psychopatyczne. Mimo wysiłków nie opracowano jednak zadowalającej teorii zakładania i upadku firm. Zupełnie niedawno w polskim czasopiśmie o randze międzynarodowej doniesiono o odkryciu o tym, że ,The interesting interpretation of the theory of development and bancruptcy of firms is based on the biologic theory developed by Darwin". Odkrycie to, mało jeszcze znane, pozwoliło rozwiązać wiele problemów związanych z ,życiem" firm; tak, z życiem, bo w myśl tej nowej teorii one żyją! Nowe spojrzenie pozwoliło udowodnić fundamentalną równość:

$$
\frac{\partial n(t, a)}{\partial t}+\frac{\partial n(t, a)}{\partial a}=-\lambda n(t, a),
$$

gdzie:

$n(t, a)=\frac{\partial N(t, a)}{\partial a}-$ gęstość rozkładu wieku życia w populacji firm. 
PRZEGLAD STATYSTYCZNY

Nr 12 (18)

Curiosum: funkcja $N(t, a)$ przybiera wartości ze zbioru liczb całkowitych, zdefiniowano ją jako ,a number of companies which in moment $t$ are not older than $a,[\ldots] n(t, a)$ represents number of companies which in moment $t$ are in age $a$ ". Ta niby gęstość definowana jest jako pochodna funkcji całkowito-liczbowej.

Takie samo równanie stosowane jest w badaniach dynamiki układu krwinek czerwonych, więc, jak łatwo zauważyć, za pomocą tak prostego, jednego równania twórcom nowej (pan)teorii udało się opisać zarówno rozwój oraz bankructwo firm, jak i urodzenia oraz zgony ludzi, a także powstawanie i zanikanie czerwonych ciałek krwi.

Żyją nie tylko firmy, ale i produkty przez nie wytwarzane. W popularnym podręczniku z logistyki czytamy bowiem: „Przedział czasu od wprowadzenia produktu na rynek do momentu jego wycofania z rynku nazywamy cyklem życia produktu". Wyróżnia się trzy fazy tego cyklu: produkt jest „gwiazdą”, jest „krową dojną”, a w schyłkowym okresie życia jest „kulą u nogi”. Słowo „cykl” jest pochodzenia greckiego oznaczającego koło. Marketingowcy, mówiąc o trzech fazach cyklu życiowego produktu, mają na uwadze doczesne rynkowe życie produktu, nie wykluczając i dalszego, pozarynkowego życia. Wielkie odkrycia naukowe powstają $\mathrm{w}$ wyniku zaobserwowania analogii. Wiadomo od dawna, że żywe istoty mają inteligencję. Wystarczyło zastosować podstawową regułę wnioskowania logicznego, modus ponens, aby stwierdzić: skoro produkty żyją, mają więc inteligencję. Pierwszym odkrywcą jest niewątpliwie J. McCarthy, on to bowiem po raz pierwszy zauważył, że jego termostat ma inteligencję, co prawda nie bardzo wysoką, bo przekonania jego termostatu dotyczą tylko temperatury otoczenia. Ale profesor S. Bamberg wynalazła, ,inteligentne wkładki do butów współpracujące z aplikacją na smartfona, które informują użytkownika, czy jego chód jest poprawny". Gdy czytamy informacje o butach inteligentnych czy klinach do majtek ,odstraszających bakterie", to można by myśleć, że to sztuczki marketingowców, których stać na wszystko, aby omglić naturalną inteligencję konsumenta. Ależ skąd! Na AGH jest katedra, która ,prowadzi prace i badania naukowe nad zastosowaniem materiałów inteligentnych w różnorodnych obiektach technicznych”. Materiały takie, jak informuje ta katedra, ,posiadają cechy sensora, procesora i urządzenia wykonawczego". W 2006 r. obroniona była praca doktorska „Mechatroniczne człony wykonawcze z zastosowaniem materiałów inteligentnych”. Mechatronika zaś jest „synergiczną kombinacją mechaniki precyzyjnej, elektronicznego sterowania i systemowego myślenia przy projektowaniu produktów i procesów produkcyjnych". Niedawno przeczytałem w Internecie, że cały 
budynek, w którym w jednej z sal miałem wykład, jest inteligentny, słuchacze, którzy przyszli, byli też inteligentni. Tak jak w dowcipie: przyszła baba do lekarza. Żartować jednak nie można, oto nakładem Polskiej Akademii Nauk wydano w 2013 r. pracę, w której prawie dziesiątka profesorów specjalizujących się w specjalizacjach inteligentnych pisze poważnie o ,dylematach polityki innowacyjnej zorientowanej na inteligentne specjalizacje".

\section{Religia i zaklęcia statystyczne}

W sierpniowym numerze czasopisma „The American Statistician” z 1985 r. ukazał się wielce zabawny, ale jednocześnie i smutny, artykuł pt. The religion of statistics as practiced in medical journals. Autor tego artykułu D.S. Salzburg informuje czytelników, że po 17 latach kontaktów z lekarzami odkrył, że wielu z nich jest wyznawcami religii o nazwie „statystyka”. Głównym celem tej religii jest oczywiście zbawienie, które osiągnąć można poprzez publikacje $\mathrm{w}$ czasopismach $\mathrm{z}$ wysoką punktacją. Przekłada się to nie tylko na awans, wyższe zarobki, ale także życie pośmiertne zapewnione poprzez cytowania. Podstawowy rytuał tej religii to hunting for p-value, wsparty używaniem magicznych zaklęć w postaci significant i stosowaniem tajemnych znaków: SD, SE, NS. Wartość statystyki wprowadzonej przez Fishera nie musi być wcale podawana, zupełnie wystarczy NS. A najlepiej użyć znaczków * lub **, a *** jest to już mirabili dictu! Do wyznawców z dyplomami lekarskimi thumnie przyłączyli się psychologowie, jednak ich wyznanie trudno na razie scharakteryzować za pomocą normalnej polszczyzny. Jako przykład niech posłuży badanie, jakie przeprowadziła pewna grupa pod przewodem znanego psychologa $\mathrm{z}$ tytułem i kompetencjami. Badaniem objęto 2503 osoby bezrobotne. Dokonano pomiaru ich samooceny, która była „mierzona za pomocą Skali Samooceny Rosenberga (0-8), w thumaczeniu Czapińskiego (1994), $M=5,26 ; S D=, 19 ; \alpha=, 736 ;$ korelacja międzypołówkowa - ,51; wspótczynnik korelacji Spearmana-Browna = ,67; $\alpha$, cz. $1=, 59 ; \alpha$, cz. $2=, 64$ ”. Już i to by wystarczyło do zilustrowania zaklęć statystycznych stosowanych przez psychologów. Ale warto zacytować wynik badania dotyczący poczucia szczęścia tych bezrobotnych. „Dzienny czas poczucia szczęścia wpływa pozytywnie (beta $=, 15 ; r=, 46 ; s r=11 ; F=29,17$; $p<, 001)$, a dzienny czas poczucia nieszczęścia wpływa negatywnie (beta $=-, 16 ; r=-, 46 ; s r=-, 12 ; F=34,78 ; p<, 0001$ ) na ogólne poczucie szczęścia w ostatnich dniach. Ten wynik ma charakter logiczny i trudno byłoby spodziewać się innego". 
PRZEGLAD STATYSTYCZNY

Nr 12 (18)

Być może jest to i prawda, że wynik ma „charakter logiczny”, choć całość sprawia wrażenie bełkotu nielogicznego upstrzonego tajemnymi znaczkami. Podobne zaklęcia występują nawet w pracach publikowanych w znanym polskim czasopiśmie statystycznym. Na cóż by się zdało proste twierdzenie, że „,podejmując decyzję o zakupie piwa konsument nie ma najczęściej czasu na analizę wszystkich dostępnych na rynku marek", gdyby nie zostało to potwierdzone poprzez istotność współczynników beta i $R$-kwadrat. Aby to wykazać, przeprowadzono stosowne badania, w których „Założono następującą hipotezę - większy wpływ na decyzję o wyborze marki wywierają argumenty emocjonalne niż racjonalne" (pogrubienie tekstu dodano), w wyniku badania (statystycznego) wykazano między innymi, że ,wartość współczynnika $\beta$ w przypadku afektu, jak i postawy przybiera wartości ujemne". Wynik ten wyjaśniono tak: ,im większa odległość konsument - marka Perła, tym mniejsza postawa i afekt do Perły". Prawdziwa perełka!

Od 2011 r. realizowano projekt europejski dotyczący modernizacji statystyki, pewnie już go zakończono, ale w 2011 r. informowano, w jednym z polskich czasopism statystycznych, iż w jego realizacji „,bierze udział 8 narodowych instytucji statystycznych z: Grecji, Niderlandów (sic!), Norwegii, Polski, Szwecji, Szwajcarii, Węgier i Włoch”. Strona polska była liderem tworzenia dwóch rozdziałów podręcznika, proponując wiele innowacji. „W zakresie imputacji opartej na dawcach danych skoncentrowano się na imputacji losowej oraz niektórych metodach deterministycznych, prowadzących do wyboru najlepszego dawcy - w tym rangowej, jak również opartej na odległościach biorców od dawców". Tym razem jest tajemne używanie myślnika i pojęcia odległości. Recenzenci z całą pewnością wiedzieli, że w zaklęciach tych jest głębszy sens. Na tym przecież polega sens statystyki.

Chciałoby się zapytać, czy jest jakiś sens przypominania, iż Polacy nie gęsi, jeśli tak powszechne jest gęganie ze strony zarówno polityków, jak i intelektualistów? Intelektualiści pracują na swój własny wstyd, politycy zaś uzupełniają niechlubną listę tzw. polskiego dokumentu wstydu, której tytuł nadał ostatni premier przedwojennej Polski, prosząc Roosevelta o pożyczkę 100 dolarów na ratowanie swego życia, a której Sikorski mu odmówił. Na świecie ludzie ubezpieczają się na wypadek wypadku, ale w Polsce sam wypadek się ubezpiecza. Tak bowiem nakazuje ustawa, uchwalona przez posłów Sejmu polskiego i podpisana przez Prezydenta państwa polskiego. Na moje sugestie spolszczenia tekstu, obywatele mający kompetencje z ubolewaniem stwierdzali, że ustawy zmienić nie można. Wypadek i tej wpadki będzie więc bezpieczny. 